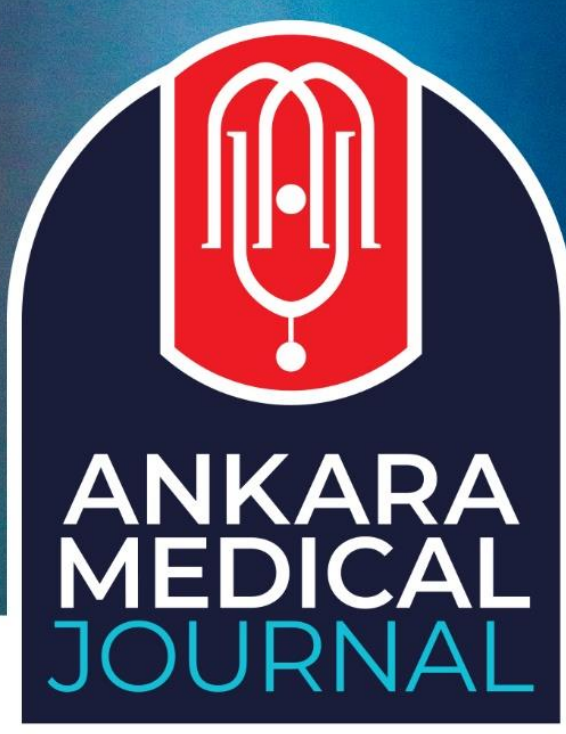

Araştırma Makalesi

Ankara Med J, 2021;(1):99-114 // 10.5505/amj.2021.57805

COVID-19 ŞÜPHESIYYL YOZGAT ŞEHİR HASTANESİNE YATAN OLGULARDA RT-PCR SONUÇLARI VE TORAKS BT GÖRÜNTÜLEME ÖZELLİKLERİ

\title{
RT-PCR RESULTS AND CHEST CT IMAGING FEATURES \\ IN PATIENTS HOSPITALIZED TO YOZGAT CITY HOSPITAL WITH COVID-19 SUSPICION
}

(D) Ahmet Tanyeri ${ }^{\mathbf{1}}$

1Yozgat Şehir Hastanesi, Radyoloji Birimi, Yozgat

Yazışma Adresi / Correspondence:

Uzm. Dr. Ahmet Tanyeri (e-posta: dr.a.tanyeri@gmail.com)

Geliş Tarihi: 17.08.2020 // Kabul Tarihi: 05.02.2021

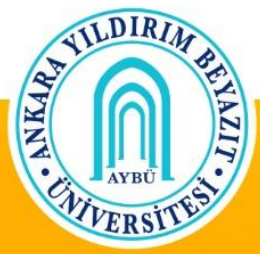

Ankara YIldırım Beyazıt University Faculty of Medicine 


\section{Öz}

Amaç: Bu çalışmanın amacı COVID-19 şüphesiyle hastaneye yatırılan olguların Toraks BT bulgularını ve RTPCR sonuçlarını incelemektir.

Materyal ve Metot: 15 Mart-15 Mayıs 2020 tarihleri arasında, Yozgat Șehir Hastanesine COVID-19 şüphesiyle yatırılan olgular geriye dönük olarak değerlendirilmiştir. Toraks BT bulguları bu çalışma için oluşturulan modifiye COVID-19 raporlama sistemine göre sınıflandırılmıştır. RT-PCR referans tanı testi kabul edilerek BT'nin tanısal performansı değerlendirilmiştir.

Bulgular: Toplam 498 olgu [54 $\pm 22(0 ; 96)]$ çalışmaya dahil edildi. Erkek olgu sayısı [323 (\%65)] kadınlardan [175 (\%35)] daha fazlaydı. Olguların 94'ünde (\%19) RT-PCR testi pozitif sonuçlanmıştı. Test sonucu pozitif olan hastaların negatif olanlara göre daha küçük yaşta olduğu bulundu. 173 (\%35) olguda toraks BT pozitif saptandı: \%13 COVID-19 uyumlu bulgular, \%7 yüksek şüpheli bulgular, \%15 düşük şüpheli bulgular. BT'nin duyarlılığı \%49, özgüllüğü \%69, RT-PCR'ın duyarlılı̆̆ı ise \%69 olarak bulundu. BT pozitif olgulardaki infiltrasyonların \%52'si her iki akciğerde, \%40'ı tüm loblarda, \%34 alt loblarda, \%47'si arka, \%43'ü ön ve arka akciğer alanlarında, \%60'ı periferik, \%30'u periferik ve santral akciğer alanlarında görüldü.

Sonuç: Toraks BT'nin COVID-19 tanısındaki duyarlılığı göreceli düşük ancak özgüllüğü yüksek bulunmuştur. BT'nin hızlı tanı için COVID-19 prevalansının yüksek olduğu bölgelerde kullanılması daha faydalı olabilir. BT bulgularını yorumlamada standardize edilmiş bir rapor formatını kullanmak hasta yönetimi için gerekli görünmektedir.

Anahtar Kelimeler: COVID-19, RT-PCR, pandemi, toraks BT, toraks BT Sinıflaması.

\footnotetext{
Abstract

Objectives: This study aims to investigate Chest CT findings and RT-PCR results in patients hospitalized with suspicion of COVID-19.

Materials and Methods: Between 15 March and 15 May 2020, patients hospitalized in Yozgat City Hospital with suspicion of Covid-19 were evaluated retrospectively. Chest CT findings were classified according to the modified COVID-19 reporting system created for this study. RT-PCR reference diagnostic test was accepted and the diagnostic performance of CT was evaluated.

Results: A total of 498 patients $[54 \pm 22(0 ; 96)]$ were included in the study. The number of male patients [323 $(65 \%)]$ was higher than female [175 (35\%)]. RT-PCR test was positive in $94(19 \%)$ of the patients. Patients with positive test results were found to be younger than negative ones. Chest CT was positive in 173 (35\%) patients: 13\% COVID-19 typical findings, 7\% high suspect findings, $15 \%$ low suspect findings. The sensitivity of CT was $49 \%$, the specificity was $69 \%$, and the sensitivity of RT-PCR was $69 \%$. Infiltrations in CT positive cases were seen in the following areas: $52 \%$ in both lungs, $40 \%$ in all lobes, $34 \%$ in lower lobes, $47 \%$ in the posterior, $43 \%$ in the anterior and posterior lung regions, $60 \%$ in the peripheral, $30 \%$ peripheral and central lung regions.

Conclusion: The sensitivity of chest CT in the diagnosis of COVID-19 was relatively low, but had high specificity. It may be more beneficial to use CT for rapid diagnosis in regions with a high prevalence of COVID19. Using a standardized report format to evaluate CT findings seems necessary for patient management. Keywords: COVID-19, RT-PCR, pandemic, Chest CT, COVID-19 classification.
} 


\section{Giriş}

COVID-19 (koronavirüs hastalığı 2019) ilk kez Ocak 2020'nin başlarında Wuhan, Hubei, Çin'de başlayan ve hızla dünya geneline yayılarak 11 Mart'ta Dünya Sağlık Örgütü tarafından küresel pandemi olarak kabul edilen şiddetli akut solunum yolu hastalı̆̆ıdır. ${ }^{1}$ Türkiye'de ilk COVID-19 vakası 10 Mart'ta saptanmıştır; 1 Ağustos 2020 tarihi itibariyle toplam 231.869 pozitif vaka mevcuttur.

COVID-19 tanısında RT-PCR (Reverse Transcription Polymerase Chain Reaction) altın standart tanı testi olarak kabul edilmektedir. Bununla birlikte testin değişken duyarlıllğı ve geç sonuç vermesi (24-48 saat $\left.{ }^{2}\right)$ gibi önemli dezavantajları mevcuttur. Test negatif olsa bile hastalık şüphesi yüksek olanlarda testin tekrarlarını uygulamak gerekmektedir. ${ }^{3}$ Bu durum, hızlı tanı ve izolasyon gerekliliği bulunan bu hastalık için ek tanı yöntemi ihtiyacı doğurmuştur. Bilgisayarlı tomografi (BT)'nin COVID-19 tanı ve tedavi takibindeki anahtar rolü kabul edilmiştir. ${ }^{4,5}$ Ancak bazı bilimsel araştırma örgütleri BT'nin rutin kullanımını önermemektedir. ${ }^{6,7}$ Her ne kadar BT’nin rutin kullanımı önerilmese de bazı ülkeler BT'yi tarama testi olarak kullanmaktadır. ${ }^{2,8,9}$ Gelişmiş ülkelerde dahi laboratuvar tanı test kitleri sınırlı sayıda iken gelişmekte olan ülkelerde BT, test kiti yetersizliği sebebiyle tek tanı yöntemi olabilmektedir. ${ }^{10}$ Ancak COVID-19 ile diğer bazı akciğer hastalıklarının BT bulgularında örtüşme olmasından dolayı BT’nin yorumlanmasında kafa karışıklığı olabilmektedir. Hastalığa özgü kabul edilen bulgular olduğu gibi yeni veriler ışığında mevcut bilgiler sürekli güncellenmektedir. Bu sebeple kapsamı genişletilmiş ve standardize edilmiş COVID-19 raporlama formatı hastalığın yönetimi için gerekli görünmektedir.

Bu çalışmada, RT-PCR testi ve toraks BT’nin COVID-19 tanısındaki duyarlılıklarını saptamak amaçlanmıştır.

\section{Materyal ve Metot}

Çalışmaya yerel etik kurul onayı ve Türkiye Cumhuriyeti (TC) Sağlık Bakanlığı'nın onayı alınarak başlandı. Yozgat Şehir Hastanesi 1 Nisan 2020 tarihi itibariyle Yozgat ili için pandemi hastanesi olarak kabul edilmiştir. İl kapsamında COVID-19 tanısı veya şüphesi olan olgular hastanemize yönlendirilmektedir. Bu çalışmada 15 Mart-15 Mayıs 2020 tarihleri arasında hastanemize COVID-19 şüphesi ile yatışı yapılan olgular geriye dönük olarak değerlendirilmiştir.

\section{Hasta Popülasyonu}

Çalışmaya RT-PCR testi yapılan ve toraks BT tetkiki bulunan olgular dahil edildi. Test yapılan fakat BT tetkiki olmayan olgular ile BT görüntüleri çeşitli sebeplerle değerlendirme kalitesinde olmayan olgular çalışma dışı bırakıldı. Ayrıca test uygulandıktan sonra en geç 48 saat içinde çekilmiş BT görüntüsü olanlar çalışmaya dahil 
edilip olguların yalnızca ilk BT tetkiki değerlendirildi. Ek olarak, ilk testi negatif olup tekrarlayan testlerde pozitiflik saptanan olgularda, pozitif çıkan testten \pm 2 gün içerinde BT tetkiki olması şartı arandı. COVID-19 şüphesiyle yatan toplam 623 hastadan çalışma şartlarını sağlamayan 125'i çıkarıldıktan sonra geriye kalan 498 olgu çalışmaya dahil edildi.

Olguların yaş ve cinsiyeti içeren demografik bilgileri hastane bilgi yönetim sistemi üzerinden kaydedildi. RTPCR testi dış merkez laboratuvarlarda çalışılmıştı; hastane bilgi yönetim sistemi üzerinden "e-Nabız" uygulamasına bağlanılarak olguların test sonucu (pozitif-negatif) öğrenildi. Birden fazla testin yapıldığı olgularda testin herhangi birinde pozitif olması durumunda olgu "COVID-19 pozitif" olarak kabul edildi. Yapılan test veya testlerin hiçbirinde pozitiflik saptanmayan olgular "COVID-19 negatif" olarak kabul edildi.

\section{Bilgisayarlı Tomografi}

Toraks BT görüntüleri Siemens SOMATOM Scope 16 (Siemens Healthineers, Erlangen, Germany) marka cihazdan (tüp voltajı $120 \mathrm{kV}$, tüp akımı 70-168 mAs, pitch 0,8-1,2 mm, kesit kalınlı̆̆ 3 mm) elde edildi. Parankimal infiltrasyonlar $1 \mathrm{~mm}$ kesit kalınlığındaki yüksek çözünürlüklü rekonstrüksiyon görüntülerden değerlendirildi. Pulmoner emboli kuşkusu da olan 6 olgu haricinde tüm tetkikler kontrastsız elde edilmişti.

\section{Görüntü Analizi}

Tüm toraks BT görüntüleri medikal monitörde, syngo.via (Siemens Healthcare GmbH, Erlangen, Germany) adlı lisanlı radyoloji görüntüleme modülünde değerlendirildi.

Herhangi bir bulgusu olmayan tetkik "Normal Toraks BT" olarak kaydedildi. Bulgu saptanan her tetkik için görüntülerin değerlendirmesinde çalışma için standardize edilmiş bir akış şeması izlendi. Öncelikle baskın olan birincil bulguya göre "dominant patern" belirlendi; bulgular aşağıda belirtilen infiltrasyon örneklerine göre sinıflandirıldı.

\section{Buzlu Cam Opasitesi (BCO)}

a) Diffüz-Yamasal: Lobar veya segmental dağılım gösteren geniş BCO.

b) Fokal: Bir veya bir kaç sekonder pulmoner lobülü içeren, belirli bir dağılım özelliği göstermeyen BCO. Tek ya da birbirine yakın olmayan sayıca 2 veya 3 farklı lokalizasyondaki BCO bu gruba dâhil edilmiştir.

c) Multi-Fokal: Sayıca 3'ten fazla farklı lokalizasyondaki fokal BCO'lar. 


\section{Konsolidasyon}

a) Pür konsolidasyon: Lobar veya segmental yerleşimli, BCO içermeyen, viral etyolojiden uzak infiltrasyon.

b) BCO'nun eşlik ettiği konsolidasyon: BCO zemini içerisinde konsolide alanlar içeren infiltrasyon. Görsel olarak değerlendirilen BCO/konsolidasyon miktarına göre "BCO az" ve "BCO baskın" olarak iki gruba ayrıldı.

\section{Diğer}

a) İșaretler: Konsolidasyon ve/veya BCO ile ilişkili veya ilişskisiz saptanan bulgular.

- Tomurcuklanmış ağaç manzarası, halo işareti, ters halo işareti, kaldırım taşı manzarası, vasküler genişleme, peribronşiyal kalınlaşma, retikülonodüler görünüm, erimiş şeker işareti ("melted sugar sign”)

b) Sekel: Konsolidasyon ve/veya BCO’ya eşlik eden veya ikisinden biri olmadığında “dominant patern" olarak seçilen bulgular. Birden fazla sekel bulgu olduğunda her biri ayrı olarak kaydedildi.

- Atelektazi, amfizem, bronşiektazi, mozaik perfüzyon, intertisyel akciğer hastalığı (İAH)

c) Lenfadenomegali (LAM): Hiler ve/veya mediastinal yerleşimli kısa aksı 1 cm'den uzun kalsifikasyon içermeyen büyümüş lenf nodları dahil edildi.

d) Efüzyon: Plevral ve/veya perikardiyal zarlar arasında biriken sıvı. Plevra ile ilişkili hastalıklara (örn: mezotelyoma) ikincil gelişen kronik efüzyon dâhil edilmedi.

e) Nodül-kitle: Enfektif süreçle ilişkisiz, tek ya da multipl, benign ya da malign karakterdeki solid lezyonlar dâhil edildi.

Dominant patern ve varsa eşlikçi diğer bulgular kaydedildikten sonra baskın bulgunun yerleşim yeri ve dağılım özellikleri aşağıda belirtilen gruplara göre sınıflandırıldı.

1. Yerleştiği akciğer: Sağ veya sol akciğer, unilateral; her iki akciğer, bilateral.

2. Yerleştiği lob (lar):

- Tüm loblar: Her iki akciğerde toplam 4 veya 5 lobu tutan.

- Sağ akciğer tüm loblar: Sağ akciğerde 2 veya 3 lobu tutan. 
- Sol akciğer tüm loblar: 2 lobu birden tutan.

- Bilateral üst loblar: Her iki akciğer üst lobu.

- Bilateral alt loblar: Her iki akciğer alt lobu.

- Unilateral alt: Sağ veya sol akciğer alt lobu.

- Unilateral üst: Sağ veya sol akciğer üst lobu.

- Sağ akciğer orta lob: İzole orta lobu tutan.

\section{Dağılım Özellikleri}

- Ön akciğer alanları: Mediastenin ortasından geçen hayali çizginin ön tarafında yerleşen.

- Arka akciğer alanları: Mediastenin ortasından geçen hayali çizginin arka tarafında yerleşen.

- Periferik akciğer alanları: Akciğerin distal 1/3'lük kesiminde yerleșen.

- Santral (perihiler) akciğer alanları: Akciğerin proksimal 2/3’lük kesiminde yerleşen.

Dominant paternin yerleşim yeri ve dağılımı saptandıktan sonra sonuca karar verildi: COVID-19 uyumsuz bulgular, COVID-19 düşük şüpheli bulgular, COVID-19 yüksek şüpheli bulgular, COVID-19 uyumlu bulgular. Sonuç kararı, Kuzey Amerika Radyoloji Derneği ("RSNA: Radiological Society of North America” ) ve Hollanda Radyoloji Derneği'nin (“NVvR: Nederlandse Vereniging voor Radiologie”) yayınladığı COVID-19 BT sınıflamaları modifiye edilerek, bu çalışma için oluşturulmuş yeni bir sınıflama sistemine göre belirlendi. ${ }^{11,12}$ Sirasıyla NVvR ve RSNA'ya göre CO-RADS 1 ("COVID-19 Reporting and Data System”) ve "pnömoni bulgusu yok" bu çalışmadaki "Normal Toraks BT" grubuna, CO-RADS 2 ve "atipik bulgular" COVID-19 uyumsuz bulgulara, CO-RADS 3 ve "belirsiz görünüm” COVID-19 düşük şüpheli bulgulara, CO-RADS 4 ve yine "belirsiz görünüm” COVID-19 yüksek şüpheli bulgulara, CO-RADS 5 ve “tipik görünüm” COVID-19 uyumlu bulgulara benzemektedir. Bu çalışmadaki BT sınıflamasının hangi bulgu ve dağılım özelliklerine göre oluşturulduğu ve tablo 1'de özetlenmiştir. BT'de saptanan infiltrasyon örneklerinden birkaçı şekil 1'de gösterilmiştir.

\section{İstatistiksel analiz}

İstatistiksel analiz SPSS (version 21.0; SPSS Inc., Chicago, IL, USA) ve Med Calc (version 19; MedCalc Software Ltd, Ostend, Belgium) yazılım programı kullanılarak yapıldı. Verilerin normalize dağılıma uyup uymadığı 
Kolmogorov-Smirnov veya Shapiro-Wilk testi kullanılarak araştırıldı. Normal dağılım gösteren yaş verileri için “ortalama \pm standart sapma (minimum; maksimum)” şeklinde gösterin tercih edildi. Yaş verisi için testi pozitif ve negatif olanlar arasındaki ilişki $\mathrm{T}$ test ile bulundu. İki veya daha fazla nominal bağımsız değişkenler arasındaki ilişki ki-kare testi ile araştırıldı. RT-PCR testi referans alınarak toraks BT için \%95 CI (confidence interval: güven aralı̆̆ı) ile duyarlılık, özgüllük, pozitif prediktif değer (PPD), negatif prediktif değer (NPD), pozitif-negatif LR (likelihood ratio: olasılık oranı) ve doğruluk bulundu. Sonuçlarda p<0,05 istatistiksel olarak anlamlı kabul edildi.

\section{Bulgular}

Toplam 498 olgu [Yaş: 54ะ22 (0; 96), E-K: 323 (\%65)-175 (\%35)] çalışmaya dahil edildi. Olguların 94'ünde (\%19) RT-PCR testi pozitif, 404'ünde (\%81) RT-PCR testi negatif olarak sonuçlanmıştı. Testi pozitif olanların ortalama yaşı 45 20 (1; 87), 64'ü (\%68) erkek, 30’u (\%32) kadındı. Testi negatif olanların ortalama yaşı $56 \pm 22$ (0; 96), 259’u (\%64) erkek, 145’i (\%36) kadındı (Şekil 2). Testi pozitif olanların yaşı negatif olanlara göre istatistiksel olarak anlamlı derecede düşük saptandı (ki kare, p=0,023). Testi pozitif ve negatif olanlar arasında erkek/kadın oranında anlamlı farklılık saptanmazken her iki grup içerisinde erkek olgu sayısı anlamlı derecede yüksek saptandı (ki kare, p=0,034).

RT-PCR testi pozitif olan 94 olgunun BT incelemesinde, 27'sinin (\%29) COVID-19 uyumlu, 10'unun (\%11) şüphesi yüksek, 9'unun (\%10) şüphesi düşük, 31'inin (\%33) uyumsuz bulguları olduğu, 17'sinde (\%17) ise herhangi bir bulgu olmadığı (normal BT) saptandı. Testi negatif olan 404 olguda ise 38'sinin (\%9) COVID-19 uyumlu, 25'inin (\%6) şüphesi yüksek, 64'ünün (\%16) şüphesi düşük, 258'inin (\%54) uyumsuz BT bulguları olduğu, 59'unda (\%15) ise herhangi bir bulgu olmadığı saptandı (Şekil 2). Testi pozitif olanların BT'sinde COVID-19 uyumlu ya da şüpheli (yüksek ve düşük) bulgu saptanma oranı (\%50), testi negatif olanlara (\%31) göre yüksek bulundu.

Testi pozitif olup BT'si COVID-19 uyumlu olan olgularda, BT'de en sık görülen dominant patern multi-fokal BCO (\%48), ikinci sıklıkla BCO’nun baskın olduğu konsolidasyondu (\%22). En sık eşlik eden işaret ise vasküler genişleme (\%11), ikinci sıklıkla ters halo işareteydi (\%7). Testi pozitif, BT'de yüksek şüpheli bulgusu olanlarda en sık görülen dominant patern fokal BCO (\%60) iken 1 olguda (\%10) eşlik eden peribronșiyal kalınlaşma saptandı. Testi negatif olup BT’si COVID-19 uyumlu olan olgularda, testi pozitif olanlara benzer şekilde en sık görülen dominant patern multi-fokal BCO (\%37), ikinci sıklıkla BCO’nun baskın olduğu konsolidasyondu (\%34). En sık eşlik eden işaret ise kaldırım taşı manzarası (\%13), ikinci sıklıkla peribronşiyal kalınlaşmaydı (\%8). Testi negatif, BT’de yüksek şüpheli bulgusu olanlarda en sık görülen dominant patern BCO’nun az olduğu konsolidasyon (\%40) iken olguların \%20'sine eşlik eden peribronşiyal kalınlaşma, \%12'sinde halo işareti 
saptandı. Testi pozitif veya negatif olup BT'de düşük şüpheli bulguları olanlarda en sık görülen bulgu BCO'nun az olduğu konsolidasyondu (Tablo 2).

Tablo 1. Bu çalışmadaki BT bulgularına göre oluşturulmuş modifiye COVID-19 raporlama sistemi

\begin{tabular}{|l|}
\hline NORMAL TORAKS BT \\
\hline - Saptanan bulgu yok \\
\hline Covid-19 Uyumsuz Bulgular \\
\hline BCO'nun olmadığı: \\
- Konsalidasyon \\
- Retikülonodüler infiltrasyon \\
- Nodül-kitle \\
- İntertisyel akciğer hastalıkları \\
- Pulmoner ödem (kardiyak) \\
- Sekel değişiklikler \\
\hline Covid-19 Şüphesi Düşük Bulgular \\
\hline BCO'nun eșlik ettiği: \\
- Konsalidasyon (tek lob yerleşimli) \\
- Retikülonodüler infiltrasyon \\
- Nodül-kitle (enfektif; halo işareti) \\
$>$ Fokal BCO: tek taraf veya bilateral, santral yerleşimli \\
\hline Covid-19 Şüphesi Yüksek Bulgular \\
\hline$>$ BCO'nun eşlik ettiği konsalidasyon (bilateral, multi-fokal) \\
$>$ Fokal BCO: bilateral, periferik yerleşimli \\
$>$ Multifokal BCO: bilateral santral veya tek taraflı periferik yerleşimli \\
\hline Covid-19 Uyumlu Bulgular \\
\hline - Konsalidasyon var ya da yok: \\
- Multifokal BCO: bilateral, periferik yerleşimli \\
- Diffüz-yamasal BCO: bilateral, periferik ya da periferik ve santral yerleşimli \\
\hline
\end{tabular}

Toplam 498 olguda en sık görülen sekel bulgu atelektazi (\%56), ikinci slklıkla amfizemdi (\%17). Olguların \%30’unda nodül ve/veya kitle saptandı. RT-PCR pozitif, BT'de COVID-19 uyumlu ve şüpheli bulguları olan olguların \%22'sinde LAM, \%22'inde plevral veya plevral + perikardiyal efüzyon saptanırken, uyumsuz bulguları olanların \%3'ünde LAM, \%16'sında plevral efüzyon saptandı. RT-PCR negatif, BT'de COVID-19 uyumlu ve şüpheli bulguları olan olguların ise \%42'sinde LAM, \%30'unda plevral ve/veya perikardiyal efüzyon saptanırken, uyumsuz bulguları olanların \%32'ünde LAM, \%19'unda plevral ve/veya perikardiyal saptandı (Tablo 2). Testi pozitif veya negatif, COVID-19 uyumlu ya da şüpheli BT bulguları olanlarda, uyumsuz olanlara göre LAM ve efüzyonun oransal olarak daha fazla olduğu saptandı.

Testi pozitif veya negatif, COVID-19 uyumlu BT bulguları olanlarda infiltrasyonlar en sık her iki akciğerde (\%95), tüm loblarda (\%79), ön ve arka akciğer alanlarında birlikte (\%63) ve en sık periferik akciğer alanlarında izlendi (\%66). Şüphesi yüksek BT bulguları olanlarda infiltrasyonlar en sık tek akciğerde (\%66), tek taraf alt lobda (\%34), arka akciğer alanlarında (\%49) ve en sık periferik akciğer alanlarında izlendi (\%83). Şüphesi 
düşük BT bulguları olanlarda ise infiltrasyonlar en sık tek akciğerde (\%74), tek taraf alt lobda (\%39), arka akciğer alanlarında (\%57) ve en sık periferik akciğer alanlarında izlendi (\%49), (Tablo 3).

RT-PCR altın standart tanı testi, BT tarama testi olarak kabul edilip, BT'de COVID-19 pozitif bulguları olanlar (uyumlu, yüksek ve düşük şüpheli bulgular) hasta kabul edildiğinde, BT’de duyarlılı \%49 (\%95 CI: \%38-59), özgüllük \%69 (\%95 CI: \%64-73), PPD \%27 (\%95 CI: \%22-32), NPD \%85 (\%95 CI: \%82-88), pozitif LR 1,56 (\%95 CI: 1,21-2), negatif LR 0,74 (\%95 CI: 0,6-0,92) ve doğruluk \%65 (\%95 CI: \%60-69) olarak bulundu. RTPCR testi negatif olan 404 olgunun BT'de COVID-19 pozitif bulguları olan 127'sinde hastalık olma ihtimali bulunduğundan, RT-PCR testinin duyarlılığı \%69 kabul edildi. COVID-19 pozitif BT bulguları olanlar içerisinden, düşük şüpheli bulguları olanlar çıkartıldığında ise RT-PCR testinin duyarlılı̆̆ı \%84'e yükselmektedir.

Tablo 2. RT-PCR sonucuna göre BT görüntüleme bulguları

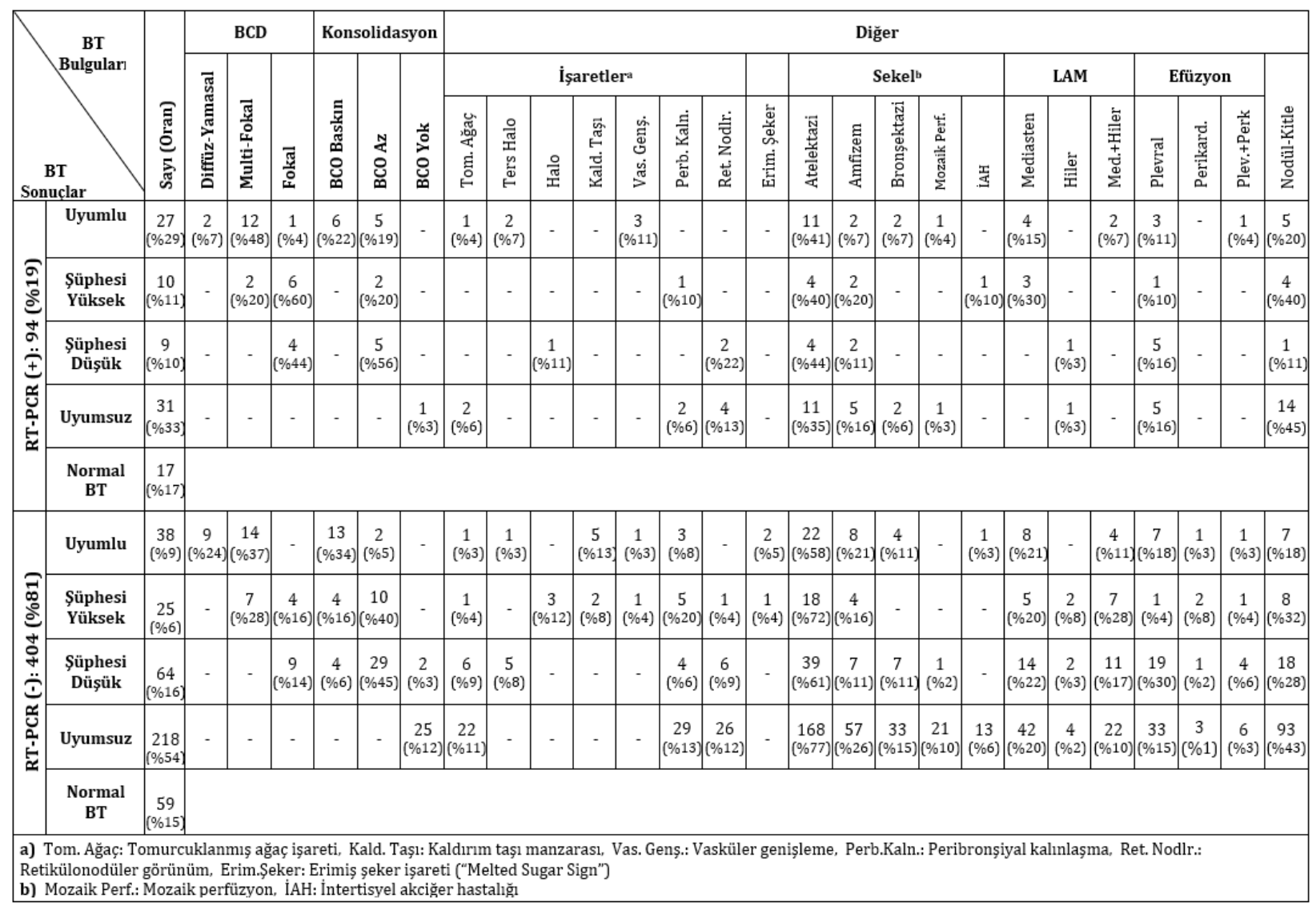


Tablo 3. RT-PCR sonucuna göre BT bulgularının yerleşim yeri ve dağılım özellikleri

\begin{tabular}{|c|c|c|c|c|c|c|c|c|c|c|c|c|c|c|c|c|c|c|}
\hline \multirow{3}{*}{\multicolumn{2}{|c|}{$\underset{\text { Sonuç }}{\text { BT }}$}} & \multirow{4}{*}{ 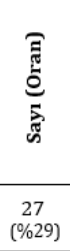 } & \multicolumn{2}{|c|}{$\begin{array}{c}\text { Akciğer } \\
\text { (ler) }\end{array}$} & \multicolumn{8}{|c|}{ Lob (lar) } & \multicolumn{6}{|c|}{ Dağılım } \\
\hline & & & \multirow{2}{*}{ 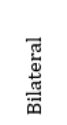 } & \multirow{2}{*}{ 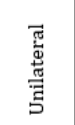 } & \multirow{2}{*}{ 咅 } & \multirow{2}{*}{ 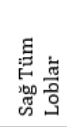 } & \multirow{2}{*}{ 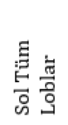 } & \multirow{2}{*}{ 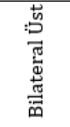 } & \multirow{2}{*}{ 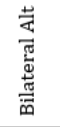 } & \multirow{2}{*}{ 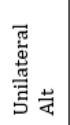 } & \multirow{2}{*}{ 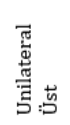 } & \multirow[b]{2}{*}{ 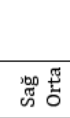 } & \multirow{2}{*}{ 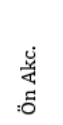 } & \multirow{2}{*}{$\begin{array}{l}\text { 岁 } \\
\text { 离 } \\
\text { 妾 }\end{array}$} & \multirow{2}{*}{ 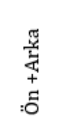 } & \multirow{2}{*}{ 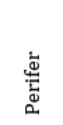 } & \multirow{2}{*}{ 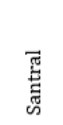 } & \multirow{2}{*}{ 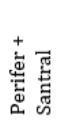 } \\
\hline & & & & & & & & & & & & & & & & & & \\
\hline \multirow{5}{*}{ 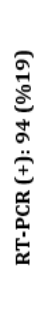 } & Uyumlu & & $\begin{array}{c}25 \\
(\% 93)\end{array}$ & $\underset{(\% 7)}{2}$ & $\begin{array}{c}19 \\
(\% 70)\end{array}$ & - & - & $\begin{array}{c}1 \\
(\% 4)\end{array}$ & $\begin{array}{c}5 \\
(\% 19)\end{array}$ & $\begin{array}{c}2 \\
(\% 7)\end{array}$ & - & - & - & $\begin{array}{c}17 \\
(\% 63)\end{array}$ & $\begin{array}{c}10 \\
(\% 37)\end{array}$ & $\begin{array}{c}21 \\
(\% 78)\end{array}$ & - & $\begin{array}{c}6 \\
(\% 22)\end{array}$ \\
\hline & Şüphesi Yüksek & $\begin{array}{c}10 \\
(\% 11)\end{array}$ & $\begin{array}{c}2 \\
(\% 20)\end{array}$ & $\begin{array}{c}8 \\
(\% 80)\end{array}$ & $\begin{array}{c}1 \\
(\% 10)\end{array}$ & - & - & - & - & $\begin{array}{c}8 \\
(\% 80)\end{array}$ & $\begin{array}{c}1 \\
(\% 10)\end{array}$ & - & $\begin{array}{c}1 \\
(\% 10)\end{array}$ & $\begin{array}{c}8 \\
(\% 80)\end{array}$ & $\begin{array}{c}1 \\
(\% 10)\end{array}$ & $\begin{array}{c}9 \\
(\% 90)\end{array}$ & $\begin{array}{c}1 \\
(\% 10)\end{array}$ & - \\
\hline & Şüphesi Düşük & $\begin{array}{c}9 \\
(\% 10)\end{array}$ & - & $\begin{array}{c}9 \\
(\% 100)\end{array}$ & - & - & - & - & - & $\begin{array}{c}4 \\
(\% 44)\end{array}$ & $\begin{array}{c}5 \\
(\% 56)\end{array}$ & - & $\begin{array}{c}1 \\
(\% 11)\end{array}$ & $\begin{array}{c}8 \\
(\% 89)\end{array}$ & - & $\begin{array}{c}4 \\
(\% 45)\end{array}$ & $\stackrel{2}{2}$ & $\begin{array}{c}3 \\
(\% 33)\end{array}$ \\
\hline & Uyumsuz & $\begin{array}{c}31 \\
(\% 33)\end{array}$ & $\begin{array}{c}11 \\
(\% 36)\end{array}$ & $\begin{array}{c}20 \\
(\% 64)\end{array}$ & $\begin{array}{c}3 \\
(\% 10)\end{array}$ & $\begin{array}{c}4 \\
(\% 13)\end{array}$ & - & $\begin{array}{c}6 \\
(\% 19)\end{array}$ & $\begin{array}{c}2 \\
(\% 7)\end{array}$ & $\begin{array}{c}7 \\
(\% 23)\end{array}$ & $\begin{array}{c}5 \\
(\% 15)\end{array}$ & $\begin{array}{c}4 \\
(\% 13)\end{array}$ & $\begin{array}{c}6 \\
(\% 19)\end{array}$ & $\begin{array}{c}22 \\
(\% 71)\end{array}$ & $\begin{array}{c}3 \\
(\% 10)\end{array}$ & $\begin{array}{c}24 \\
(\% 84)\end{array}$ & $\begin{array}{c}1 \\
(\% 3)\end{array}$ & $\begin{array}{c}4 \\
(\% 13)\end{array}$ \\
\hline & Normal BT & $\begin{array}{c}17 \\
(\% 17)\end{array}$ & & & & & & & & & & & & & & & & \\
\hline \multirow{5}{*}{ 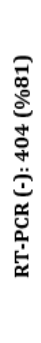 } & Uyumlu & $\begin{array}{c}38 \\
(\% 9)\end{array}$ & $\begin{array}{c}37 \\
(\% 97)\end{array}$ & $\begin{array}{c}1 \\
(\% 3)\end{array}$ & $\begin{array}{c}32 \\
(\% 84)\end{array}$ & $\begin{array}{c}1 \\
(\% 3)\end{array}$ & - & $\begin{array}{c}1 \\
(\% 3)\end{array}$ & $\begin{array}{c}3 \\
(\% 8)\end{array}$ & $\begin{array}{c}1 \\
(\% 3)\end{array}$ & - & - & - & $\begin{array}{c}7 \\
(\% 18)\end{array}$ & $\begin{array}{c}31 \\
(\% 82)\end{array}$ & $\begin{array}{c}22 \\
(\% 58)\end{array}$ & - & $\begin{array}{c}16 \\
(\% 42)\end{array}$ \\
\hline & Şüphesi Yüksek & $\begin{array}{c}25 \\
(\% 6)\end{array}$ & $\begin{array}{c}10 \\
(\% 40)\end{array}$ & $\begin{array}{c}15 \\
(\% 60)\end{array}$ & $\begin{array}{c}4 \\
(\% 16)\end{array}$ & $\begin{array}{c}10 \\
(\% 40)\end{array}$ & $\begin{array}{c}3 \\
(\% 12)\end{array}$ & $\begin{array}{c}1 \\
(\% 4)\end{array}$ & $\begin{array}{c}3 \\
(\% 12)\end{array}$ & $\begin{array}{c}4 \\
(\% 16)\end{array}$ & - & - & $\begin{array}{c}3 \\
(\% 12)\end{array}$ & $\begin{array}{c}9 \\
(\% 36)\end{array}$ & $\begin{array}{c}13 \\
(\% 52)\end{array}$ & $\begin{array}{c}20 \\
(\% 80)\end{array}$ & - & $\begin{array}{c}5 \\
(\% 20)\end{array}$ \\
\hline & Şüphesi Düşük & $\begin{array}{c}364 \\
(\% 16)\end{array}$ & $\begin{array}{c}18 \\
(\% 28)\end{array}$ & $\begin{array}{c}46 \\
(\% 72)\end{array}$ & $\begin{array}{c}12 \\
(\% 19)\end{array}$ & $\begin{array}{c}7 \\
(\% 11)\end{array}$ & $\begin{array}{c}2 \\
(\% 3)\end{array}$ & $\begin{array}{c}3 \\
(\% 5)\end{array}$ & $\begin{array}{c}4 \\
(\% 6)\end{array}$ & $\begin{array}{c}24 \\
(\% 38)\end{array}$ & $\begin{array}{c}11 \\
(\% 17)\end{array}$ & $\begin{array}{c}1 \\
(\% 2)\end{array}$ & $\begin{array}{c}12 \\
(\% 20)\end{array}$ & $\begin{array}{c}33 \\
(\% 52)\end{array}$ & $\begin{array}{c}19 \\
(\% 28)\end{array}$ & $\begin{array}{c}28 \\
(\% 44)\end{array}$ & $\begin{array}{c}18 \\
(\% 28)\end{array}$ & $\begin{array}{c}18 \\
(\% 28)\end{array}$ \\
\hline & Uyumsuz & $\begin{array}{l}218 \\
(\% 59)\end{array}$ & $\begin{array}{c}134 \\
(\% 62)\end{array}$ & $\begin{array}{c}86 \\
(\% 38)\end{array}$ & $\begin{array}{c}50 \\
(\% 23)\end{array}$ & $\begin{array}{l}12 \\
(\% 6)\end{array}$ & $\begin{array}{c}6 \\
(\% 3)\end{array}$ & $\begin{array}{c}44 \\
(\% 20)\end{array}$ & $\begin{array}{c}37 \\
(\% 17)\end{array}$ & $\begin{array}{c}31 \\
(\% 14)\end{array}$ & $\begin{array}{c}26 \\
(\% 20)\end{array}$ & $\begin{array}{c}10 \\
(\% 5)\end{array}$ & $\begin{array}{c}42 \\
(\% 19)\end{array}$ & $\begin{array}{c}83 \\
(\% 38)\end{array}$ & $\begin{array}{c}93 \\
(\% 43)\end{array}$ & $\begin{array}{l}150 \\
(\% 69)\end{array}$ & $\begin{array}{c}11 \\
(\% 5)\end{array}$ & $\begin{array}{c}57 \\
(\% 26)\end{array}$ \\
\hline & Normal BT & $\begin{array}{c}59 \\
(\% 15)\end{array}$ & & & & & & & & & & & & & & & & \\
\hline
\end{tabular}
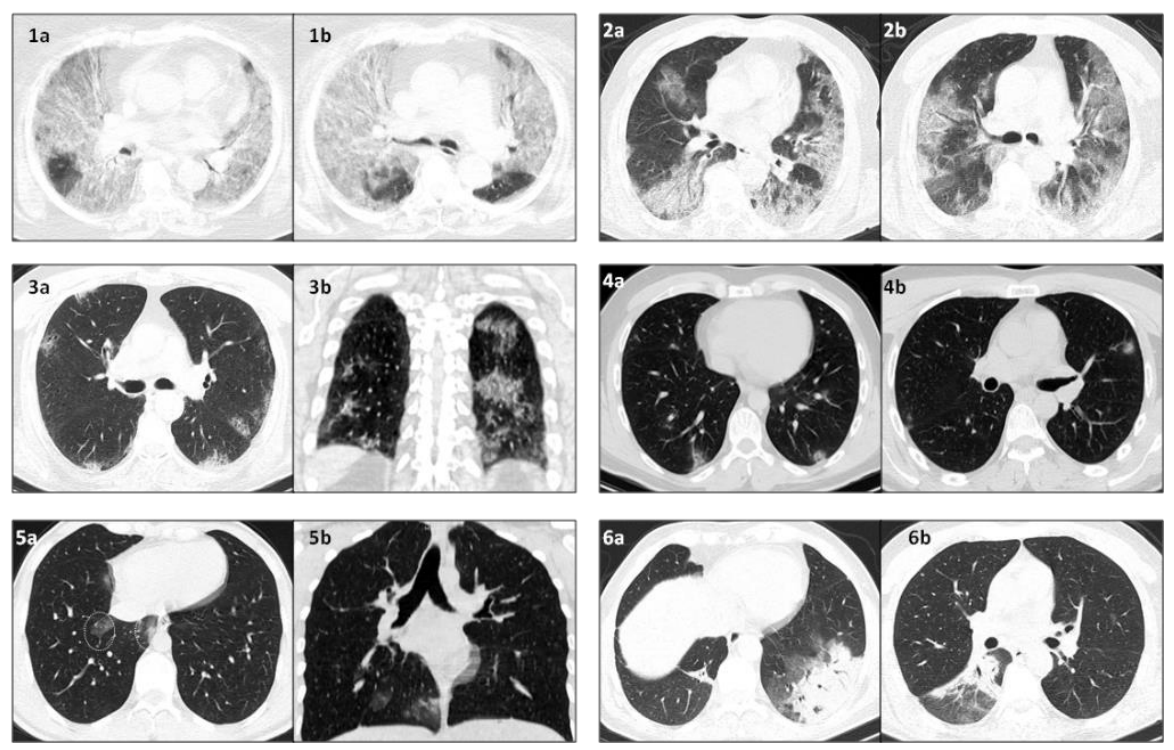

ağırlıklı olarak arka akciğer alanında, 3 farklı alanda fokal BCO.

5a; 5b) 24 y/E: RT-PCR (+) olan olguda sağ akciğer alt lobunda santral yerleşimli fokal BCO.

6a; 6b) 51 y/E: RT-PCR (-) olan olguda her iki akciğer alt lobda, arka akciğer alanlarında, ağırlıklı olarak periferik yerleşimli, konsalidasyon baskın BCO.
Şekil 1. COVID-19 șüphesiyle çekilen BT’lerdeki bazı infiltrasyon örnekleri

1a; 1b) 74 y/E: RT-PCR (+) olan olguda her iki akciğerde, tüm lob ve segmentlerde, perifer ve santralde, ön ve arka akciğer alanlarını etkileyen diffüz BCO.

2a; 2b) 80 y/E: RT-PCR (-) olan olguda her iki akciğerde, tüm lob ve segmentlerde, ağırlıklı olarak periferde, ön ve arka akciğer alanlarını etkileyen yamasal BCO.

3a; 3b) 57 y/E: RT-PCR (-) olan olguda her iki akciğerde, tüm lob ve segmentlerde, periferik yerleşimli, ön ve arka akciğer alanlarında, 3'ten fazla farklı alanda multi-fokal BCO. 4a; 4b) 41 y/E: RT-PCR (+) olan olguda her iki akciğer alt lobu ve sol üst lobda, periferik yerleșimli, 


\begin{tabular}{|c|c|c|}
\hline & \multicolumn{2}{|c|}{$\begin{array}{c}\text { Covid-19 şüpheli hasta (n: 623) } \\
15 \text { Mart-15 May 1s }\end{array}$} \\
\hline \multicolumn{3}{|c|}{\begin{tabular}{|c|} 
Covid-19 şüpheli hasta (n: 498) \\
[Yaş: $54 \pm 22(0 ; 96)$, E-K: $323(\% 65)-175(\% 35)]$
\end{tabular}} \\
\hline$\downarrow$ & $\downarrow$ & \\
\hline $\begin{array}{c}\text { RT-PCR pozitif (n: 94) } \\
\text { Yaș: } 45 \pm 20(1 ; 87) \\
\text { E-K: } 64(\% 68)-30(\% 32)\end{array}$ & $\begin{array}{r}\text { RT-PCR neg } \\
\text { Yaş: } 56 \pm 2 \\
\text { E-K: } 259(\% 6\end{array}$ & $\begin{array}{l}\text { : 404) } \\
96) \\
(\% 36)\end{array}$ \\
\hline$\downarrow$ & 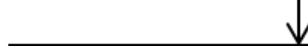 & \\
\hline Toraks BT & Toral & \\
\hline 1) Uyumlu Bulgular (n: 27) & 1) Uyumlu Bulgular & \\
\hline [Yaș: $53 \pm 21(1 ; 87)$, E-K: $21(\% 78)-6(\% 22)]$ & [Yaş: $66 \pm 18(19 ; 87), \mathrm{E}$. & $(\% 68)-12(\% 32)]$ \\
\hline 2)Yülksek Şüpheli Bulgular (n: 10) & 2)Yüksek Şüpheli Bu & $\mathbf{r}(\mathrm{n}: 25)$ \\
\hline [Yaş: $41 \pm 23(2 ; 75)$, E-K: $6(\% 60)-4(\% 40)]$ & [Yaş: $57 \pm 21(18 ; 89), \mathrm{E}$ & $(\% 72)-7(\% 28)]$ \\
\hline 3) Düş̧ük Şüpheli Bulgular (n: 9) & 3) Düşük Şüpheli Bu & $r(n: 64)$ \\
\hline [Yaş: $44 \pm 23(13 ; 81)$, E-K: $5(\% 56)-4(\% 44)]$ & [Yaş: $52 \pm 20(0 ; 88), \mathrm{E}-]$ & $(\% 64)-23(\% 36)]$ \\
\hline 4) Uyumsuz Bulgular (n: 31) & 4) Uyumsuz Bulgula & 218) \\
\hline [Yaş: $45 \pm 17(18 ; 76), \mathrm{E}-\mathrm{K}: 19(\% 61)-12(\% 38)]$ & [Yaş: $62 \pm 19(2 ; 96), \mathrm{E}-]$ & $(\% 64)-78(\% 36)]$ \\
\hline 5) Normal Toraks BT (n: 17) & 5) Normal Toraks B] & 59) \\
\hline [Yaş: $34 \pm 12(11 ; 52)$, E-K: $13(\% 77)-4(\% 23)]$ & [Yaș: $28 \pm 18(1 ; 80), \mathrm{E}-]$ & $(\% 58)-25(\% 42)]$ \\
\hline
\end{tabular}

Şekil 2. COVID-19 şüphesiyle hastaneye yatan olguların demografik özellikleri, RT-PCR test sonuçları ve BT sonuçları.

\section{Tartışma}

Bu çalışmada RT-PCR'nin COVID-19 tanı duyarlılığı Toraks BT'ye göre yüksek bulunmuştur. COVID-19 tanısında şu aşamada altın standart tanı testi RT-PCR olarak kabul edilmektedir. Bununla birlikte testin göreceli düşük ve değişken duyarlılı̆̆ı, geç sonuç vermesi etkinliğini kısıtlamaktadır. Test sonucunun doğruluğu da sorguya açıktır; bu hem örneğin elde edilme yöntemi hem de test metodu için geçerlidir. ${ }^{13} \mathrm{Bu}$ konuda yayınlanan birçok makalede örnek elde etme metodu veya RT-PCR metodu belirtilmemiştir. ${ }^{14}$ Örnek elde etme yöntemleri arasında bronkoalveoler lavaj sıvısı en duyarlısıdır ancak invazif doğası ve çalışanları tehlikeye atabilecek damlacık oluşturan bir yöntem olması nedeniyle yaygın kullanımı yoktur. Genel olarak kombine sürüntü örneği (orofarengeal ve nazofarengeal) alınması önerilmektedir. Testin değişken duyarlılığını açıklayacak sebeplerden biri örnek alma metodu olabilir. Örneğin, 1070 hastayı içeren bir çalışmada, nazal sürüntü ile pozitiflik saptanan olguların yalnızca yarısında boğazdan alınan örneklerden 
pozitiflik saptanabilmiştir. ${ }^{15}$ Kurumumuzda test için kombine sürüntü örneği alınmaktadır. Örnekler birkaç farklı dış merkezde çalışıldığından metot hakkında ise ayrıntılı bilgiye ulaşılamamıştır. Testin değişken duyarlılığını açıklayabilecek bir diğer sebep BT bulgularını yorumlamada henüz ortak fikir birliğinin oluşmaması olabilir. Test negatif olsa dahi tipik BT bulguları olan olgular COVID-19 hastası kabul edilmektedir. Ancak BT bulguları ile ilgili veriler henüz sınırlıdır, doğrulanmasına ve geliştirilmesine ihtiyaç devam etmektedir. Yapılan çalışmalarda RT-PCR testinin duyarlılı̆̆ı için \%25 ile \%98 arasında değişen oranlar bildirilmiştir. ${ }^{8,16-18} \mathrm{Bu}$ çalışmada RT-PCR testinin duyarlılığı \%69 olarak varsayılmış olup testin duyarlılığı literatüre göre orta-üst sıralarda yer almaktadır.

COVID-19 ile ilişkili akciğer infiltrasyonlarından en özgül olanı buzlu cam opasiteleridir; zemindeki bronkovasküler izleri gizlemeyen puslu akciğer dansitesi olarak tanımlanır. ${ }^{19}$ BT’nin COVID-19 tanısındaki duyarlılık ve özgüllüğü için sırasıyla \%60-98 ve \%25-53 arasında değișen oranlar bildirilmiştir.8,16-18 BT bulguları hastadan hastaya veya hastalığın evresine göre değişebilir. ${ }^{20,21}$ Bernheim ve ark. 121 semptomatik hastanın görüntüleme bulgularını, semptom başlangıcı ile hastanın BT taramasına kadar geçirdiği zamana göre tanımlamışlardır. Bu olgu serisinde, semptom başladıktan 0-2 gün sonra ("erken”) hastaların BT incelemelerinin \%56'sı normal iken, 3-5 gün sonra ("orta") sadece \% 9’unda ve 6-12 gün sonra ("geç") \% 4'ünde BT bulguları normal saptanmıştır. ${ }^{22}$ Pan ve ark. hastalığın erken evresinde büyük oranda küçük subplevral BCO’ların görüldüğünü, daha sonra iki haftaya kadar kaldırım taşı manzarası ve konsolidasyon gelişimi olduğunu bildirmişlerdir. ${ }^{23} \mathrm{Bu}$ çalışma BT bulgularını tanımlamaya yönelik tasarlandığından hastaların semptomatik olup olmadığı, semptom başlangıç zamanı ile BT arasındaki zaman ilişkisi araştırılmamıştır. Literatüre kıyasla bu çalışmadaki göreceli düşük BT duyarlılığının (\%49) sebebi bu olabilir. BT bulgularındaki özgüllüğün ise göreceli yüksek olması (\%69) bu çalışma için oluşturulan raporlama sisteminin faydalı olduğunu düşündürmektedir.

COVID-19'un tipik olarak periferik ve arka akciğer alanlarında, diffüz veya alt zon dağılımlı BCO ile ortaya çıktığı, BCO'nun tek başına veya konsolidasyonla beraber olduğu yapılan birçok çalışmada gösterilmiştir.4,22-26 Bu çalışmada literatürle uyumlu olarak COVID-19 uyumlu BT bulguları olan olgularda, infiltrasyonların baskın olarak her iki akciğerde, tüm loblarda ve periferik akciğer alanlarında olduğu görülmüştür. İzole ön akciğer tutulumu bu olguların hiçbirinde saptanmazken, ağırlıklı olarak ön ve arka akciğer alanlarının birlikte etkilendiği saptanmıştır. COVID-19 yüksek ve düşük şüpheli BT bulguları olanlarda ise infiltrasyonlar ağırlıklı olarak tek akciğerde, alt, arka ve periferik akciğer alanlarında görülmüştür. Bu dağılım paterni COVID-19 için anlamlı olsa da BCO’nun bulunduğu aksi dağılım özelliklerinde hastalık dışlanmamalıdır. Bu çalışmada düşük şüpheli BT bulguları olup, \%56 oranında tek akciğer üst lob BCO’su bulunan ve ayrıca \%22 oranında izole santral akciğer alanı tutulumu olan olgularda test pozitifliği saptanmıştır. Sonuçlarında gösterdiği üzere BT'de BCO’su olan her olgunun COVID-19 açısından değerlendirilmesi, BCO’nun miktarı ve dağılım özelliklerine göre risk açısından sınıflandırılması faydalı olacaktır. Sınıflandırılmış BT bulgularına göre olguya yaklaşım, RT- 
PCR'in değişken duyarlılığını kontrol altına almak için önemli bir yardımcı olarak kullanılabilir. Testi negatif olup klinik olarak COVID-19 kuşkusu olan olgularda test tekrarının gerekip gerekmediğine, tekrar edilecekse pozitif olma ihtimaline ya da tekrarlanacak test sayısına sınıflandırılmış BT bulgularına göre karar verilebilir. Toraks BT bulguları RT-PCR testinin pozitifleşmesinden önce ortaya çlkabilir. COVID-19'lu bir hastada başlangıçta negatif olan RT-PCR'ın pozitifleşmesi 4 günü bulabilmektedir. ${ }^{8}$ Öte yandan BT'nin rutin olarak kullanılmaması, sınırlarının çizilmesinin gerektiği de aşikârdır. Burada asıl vurgulanmak istenen BT’de bulgusu olan olgulara yaklaşımı tanımlamaktır ki bu çalışmada testi pozitif olanların \%51'inde, testi negatif olanların \%69'unda COVID-19 düşündürecek bulguya rastlanmamıştır. Hastalığın bölgedeki prevalansı başta olmak üzere, klinik semptom, temas öyküsü, RT-PCR testi veya BT’ye ulaşım olanağı vb. sebepler göz önünde bulundurularak seçilmiş olgularda BT çekilmesi uygun olacaktır. Şu aşamada ülkeler bu gibi sebeplerle kendi pandemiye yaklaşım politikasını uygulamakta ve geliştirmektedir. Çin Ulusal Sağlık Komisyonu'nun resmi tanı ve tedavi protokolünün altıncı baskısı, Toraks BT’nin COVID-19 için tanı kriterlerinden biri olduğunu belirtmektedir. ${ }^{27}$ Fleischner Derneği, COVID-19 salgını sırasında hastaların tedavisi için BT’nin rolü hakkında çok uluslu bir konsensüs bildirisi yayınlamıştır. Görüntülemenin COVID-19'dan şüphelenilen hastalarda (orta derecede-şiddetli klinik özellikler ve yüksek pre-test hastalık olasılığı) ve COVID-19 olup solunumu durumu kötüleșen hastalarda endike olduğu bildirilmiștir. ${ }^{28}$

COVID-19 hastalarının görüntülemelerinde BCO dışında farklı bulgular da tanımlanmıştır. 11 farklı çalışmayı içeren bir derlemede, BT bulguları için değişken oranlar bildirilmiştir; \%34-98 BCO, \%2-64 konsolidasyon, \%41-64 konsolidasyon ve BCO, \%5-71 kaldırım taşı manzarası, \%14-80 hava bronkogramı, \%1-53 bronşiektazi, \%9-29 peribronşiyal kalınlaşma, \%20-28 subplevral çizgi, \%59-82 vasküler genişleme, \%18-64 halo işareti, \%2-5 ters halo işareti, \%0-32 nodül, \%0-14 plevral efüzyon, \%0-32 plevral kalınlaşma, \%5-6 perikardiyal efüzyon, \%0-8 lenfadenopati. ${ }^{29}$ BT bulgularının yorumlanması ve sınıflandırılması sorguya açıktır; çalışmaların birçoğunda metodolojik yöntem ayrıntılandırılmamıştır. Ayrıca bu değişken oranlar, hastalığın evresine veya altta yatan ikincil akciğer hastalı̆̆ı varlığına bağlı olabilir. BCO dışında kaldırım taşı manzarası ve konsolidasyon varlığı hastalığın evresiyle ilişkili olarak kabul edilse de örneğin, peribronşiyal kalınlaşma, vasküler genişleme, bronşiektazi vb. bulguların mevcut hastalıkla ilişkili olup olmadığı yapılan çalışmaların birçoğunda net olarak belirtilmemiștir. Bu çalışmada COVID-19 uyumlu ya da şüpheli BT bulguları olanlarda BCO dışı ikincil bulgulardaki oranların literatüre göre göreceli düşük olması belirtildiği üzere metodolojik yöntem ile ilişkili olabilir. Çalışmada, COVID-19 uyumlu ya da şüpheli BT bulguları olanlarda, uyumsuz olanlara göre LAM ve efüzyon oransal olarak daha fazla saptanmıştır ancak COVID-19 ile ilişkili olup olmadığı hakkında yorum yapılamamaktadır.

Bu çalışmada bazı sınırlılıklar vardı. Hastaneye yatışı yapılan olgular çalışmaya dâhil edildiğinden semptomatik ya da yüksek riskli oldukları kabul edildi ancak bu öngörü doğrulanmadı; bu durum BT’deki göreceli düşük duyarlılığın sebebi olabilir. Birkaç hastada ilk test negatif olup tekrarlayan testlerde pozitiflik saptandığından 
RT-PCR için bulunan duyarlılığın doğruluğunu etkilediği kabul edilebilir. BT bulgularının yorulmasında hali hazırda ortak kanaat oluşmamıştır; bu çalışma için literatür verileri ışı̆̆ında modifiye edilen yeni bir raporlama sistemi oluşturulmuştur, doğruluğu sorguya açıktır. RT-PCR test örnekleri dış merkez laboratuvarlarda incelenmektedir, yöntem hakkında bilgi edinilememiștir.

Sonuç olarak, RT-PCR testinin COVID-19 tanı duyarlılığı BT’ye göre yüksek bulunmuştur. Yozgat ili için COVID19 prevalansı düşük olduğundan öncelikle klinik şüphesi olanlara BT tetkikinin eklenmesi akılcı bir yöntem olarak görünmektedir. Ancak bu durum geneli temsil etmemektedir, epidemiyolojik verilere göre yaklaşım farklılıkları makul olabilir. BCO saptanan olgularda, infiltrasyonun dağılım ve miktarından bağımsız COVID-19 şüphesi belirtilmelidir. İnfiltrasyon özelliklerine göre oluşturulmuş standardize BT rapor formatı ise hem radyolog hem de ilgili klinisyen için pandemi sürecinin yönetiminde ortak bir dil oluşması için gerekli görünmektedir.

Etik onay

Çalışmanın Etik Onayı Yozgat Bozok Üniversitesi Klinik Araştırmalar Etik Kurulundan 10.06.2020 tarihli 2017 KAEK-189_2020.06.10_15 karar numarası ile alınmıştır. T.C. Sağlık Bakanlığı onayı 19.05.2020 tarihli 2020-0514T15_26_48 karar numarası ile alınmıştır.

\section{Finansal Kaynak}

Bu makale ile ilgili herhangi bir finansal kaynaktan yararlanılmamıştır.

\section{Çıkar Çatışması}

Bu makale ile ilgili herhangi bir çıkar çatışması bulunmamaktadır. 


\section{Kaynaklar}

1. World Health Organization[İnternet].https://www.who.int/dg/speeches/detail/who-director-general-s opening-remarks at-the media- briefing-on-covid-19-11-march-2020 (Erişim Tarihi: 22.03.2020).

2. The BMJ Opinion [İnternet]. https://blogs.bmj. com/bmj/2020/03/20/lessons-from-the-frontline-of-thecovid-19- outbreak/ (Erișim Tarihi: 28.03.2020).

3. Jeffrey PK, Brent PL, Jonathan HC, Brett ME, Loren HK. Essentials for Radiologists on COVID-19: An Update- Radiology Scientific Expert Panel. Radiology. 2020 Feb 27;200527.

4. Chung M, Bernheim A, Mei X ve ark. CT imaging features of 2019 novel coronavirus (2019-nCoV). Radiology. 2020 Apr;295(1):202-7.

5. Pan Y, Guan H. Imaging changes in patients with 2019-nCov. Eur Radiol. 2020 Jul;30(7):3612-13.

6. American College of Radiology [İnternet]. https://www.acr.org/Advocacy-and Economics/ACR-PositionStatements/ Recommendations-for-Chest-Radiography-and-CT-for-Suspected-COVID19-Infection (Erişim Tarihi: 31.03.2020).

7. The American Society of Emergency Radiology [İnternet] https://thoracicrad.org/wpcontent/uploads/2020/03/STR-ASER-Position-Statement-1.pdf. (Erişim Tarihi: 30.03.2020).

8. Ai T, Yang Z, Hou H ve ark. Correlation of chest CT and RTPCR testing in coronavirus disease 2019 (COVID-19) in China: a report of 1014 cases. Radiology. 2020 Feb 26;200642.

9. Chen N, Zhou M, Dong X ve ark. Epidemiological and clinical characteristics of 99 cases of 2019 novel coronavirus pneumonia in Wuhan, China: a descriptive study. Lancet. 2020;395(10223):507-13.

10. Kanne JP, Little BP, Chung JH, Elicker BM, Ketai HL. Essentials for radiologists on COVID-19: an updateradiology scientific expert panel. Radiology. 2020 Feb 27;200527.

11. Simpson S, Kay FU, Abbara S ve ark. Radiological Society of North America Expert Consensus Statement on Reporting Chest CT Findings Related to COVID-19. Endorsed by the Society of Thoracic Radiology, the American College of Radiology, and RSNA. J Thorac Imaging. 2020 Apr 28.

12. Prokop M, Everdingen Wv, Vellinga TvR ve ark. CO-RADS- A Categorical CT Assessment Scheme for Patients With Suspected COVID-19: Definition and Evaluation. Radiology. 2020 Apr 27;201473. 
13. Loeffelholz MJ, Tang YW. Laboratory diagnosis of emerging human coronavirus infections - The State of the Art. Emerg Microbes Infect. 2020 Dec;9(1):747-56.

14. Xie X, Zhong Z, Zhao W, Zheng C, Wang F, Liu J. Chest CT for typical 2019-nCoV pneumonia: relationship to negative RT-PCR testing. Radiology. 2020 Feb 12;200343.

15. Wang W, Xu Y, Gao R ve ark. Detection of SARS-CoV-2 in Different Types of Clinical Specimens. JAMA. 2020 Mar 11;323(18):1843-44.

16. Wen Z, Chi Y, Zhang L ve ark. Coronavirus disease 2019: initial detection on chest CT in a retrospective Multicenter study of 103 chinese subjects. Radiology: Cardiothoracic Imaging 2020;2(2):e200092

17. Inui S, Fujikawa A, Jitsu M ve ark. Chest CT findings in cases from the cruise ship "Diamond Princess" with coronavirus disease 2019 (COVID-19). Radiology: Cardiothoracic Imaging 2020;2(2):e200110

18. Fang Y, Zhang H, Xie J, ve ark. Sensitivity of chest CT for COVID-19: Comparison to RT-PCR. Radiology. 2020 Feb 19;200432.

19. Hansell DM, Bankier AA, MacMahon H ve ark. Fleischner Society: glossary of terms for thoracic imaging. Radiology. 2008 Mar;246(3):697-722.

20. Wang D, Hu B, Hu C ve ark. Clinical characteristics of 138 hospitalized patients with 2019 novel coronavirus-infected pneumonia in Wuhan, China. JAMA. 2020 Feb 7;323(11):1061-69.

21. Ye Z, Zhang Y, Wang Y, Huang Z, Song B. Chest CT manifestations of new coronavirus disease 2019 (COVID-19): a pictorial review Eur Radiol. 2020 Mar 19;1-9.

22. Bernheim A, Mei X, Huang M ve ark. Chest CT Findings in Coronavirus Disease-19 (COVID-19): Relationship to Duration of Infection. Radiology. 2020 Jun;295(3):200463.

23. Pan F, Ye T, Sun P ve ark. Time Course of Lung Changes On Chest CT During Recovery From 2019 Novel Coronavirus (COVID-19) Pneumonia. Radiology. 2020 Jun;295(3):715-21

24. Kong W, Agarwal P. Chest Imaging Appearance of COVID-19 Infection. Radiology Cardiothoracic Imaging. Radiology: Cardiothoracic Imaging 2020; 2(1):e200028

25. Bai HX, Hsieh B, Xiong Z ve ark. Performance of radiologists in differentiating COVID-19 from viral pneumonia on chest CT. Radiology. 2020 Mar 10;200823 
26. Salehi S, Abedi A, Balakrishnan S, Gholamrezanezhad A. Coronavirus Disease 2019 (COVID-19): A Systematic Review of Imaging Findings in 919 Patients. AJR Am J Roentgenol. 2020 Mar 14;1-7.

27. Li Y, Xia L. Coronavirus disease 2019 (COVID-19): role of chest CT in diagnosis and management. AJR Am J Roentgenol. 2020 Jun;214(6):1280-86.

28. Rubin GD, Haramati LB, Kanne JP ve ark. The role of chest imaging in patient management during the COVID-19 pandemic: a multinational consensus statement from the Fleischner Society. Chest. 2020 Apr 7;S0012-3692(20)30673-5.

29. Güneyli S, Atçeken Z, Doğan H, Altınmakas E, Atasoy KÇ. Radiological Approach to COVID-19 Pneumonia With an Emphasis on Chest CT. Diagn Interv Radiol. 2020;26(4):323. 